\title{
Marijuana Induced Myocarditis: A New Entity of Toxic Myocarditis
}

\author{
Pramod Theetha Kariyanna ${ }^{1}$, Apoorva Jayarangaiah², Navneet Singh ${ }^{3}$, Teresa Song ${ }^{3}$, Stanley Soroka ${ }^{3}$, \\ Abhimanyu Amarnani ${ }^{3}$, Justina Ray ${ }^{3}$, Samy I. McFarlane, \\ ${ }^{1}$ Division of Cardiovascular Disease, Department of Internal Medicine, State University of New York, \\ Downstate Medical Center, Brooklyn, New York, U.S.A- 11203. \\ ${ }^{2}$ Department of Internal Medicine, Wake Forest University, Baptist Health System, Winston-Salem, North Carolina, U.S.A-27157. \\ ${ }^{3}$ Department of Internal Medicine, State University of New York Downstate Medical Center, Brooklyn, New York, U.S.A- 11203. \\ *Corresponding author: Samy.mcfarlane@downstate.edu
}

Received August 06, 2018; Revised September 10, 2018; Accepted September 26, 2018

\begin{abstract}
Marijuana is the most common drug of abuse in the United States. Marijuana has more than 460 active chemical compounds including $\delta$-9- tetrahydrocannabinol (THC). It acts via the $\mathrm{CB} 1$ and $\mathrm{CB} 2$ receptors that are distributed in various tissues in the body. Marijuana is known to cause tachycardia, bradycardia, hypertension, to decrease time angina, myocardial infarction and cardiac arrest. Till date, four cases of myocarditis/perimyocarditis associated with marijuana use have been reported. In one such case, it led to the development of heart failure in a young male patient. It is not clear if marijuana in and of itself causes myocarditis/perimyocarditis or if the etio-pathogenesis is actually related to the contaminants in marijuana such as pesticides and heavy metals. We hereby present a young male who with myocarditis related to marijuana use. Clinicians should have suspicion for myocarditis or perimyocarditis in patients presenting with chest pain following marijuana use.
\end{abstract}

Keywords: marijuana, myocarditis, toxic myocarditis

Cite This Article: Pramod Theetha Kariyanna, Apoorva Jayarangaiah, Navneet Singh, Teresa Song, Stanley Soroka, Abhimanyu Amarnani, Justina Ray, and Samy I. McFarlane, "Marijuana Induced Myocarditis: A New Entity of Toxic Myocarditis." American Journal of Medical Case Reports, vol. 6, no. 9 (2018): 169-172. doi: 10.12691/ajmcr-6-9-1.

\section{Introduction}

In 2016, over 26 million americans reported marijuana use within the last month [1]. Marijuana is the most commonly used drug of abuse in the United States [2]. Despite federal government's classification of the drug as a Schedule one drug, marijuana use is on a steady rise due to the legalization of marijuana in 25 states for medicinal purposes and in 8 states for recreational use [3,4]. Over 460 chemicals including $\delta$-9- tetrahydrocannabinol (THC) have been reported in marijuana [5]. Tachycardia, arrhythmias, hypotension, hypertension, and increase risk of myocardial infarction are adverse cardiovascular effects reported with marijuana use [6]. Potency of marijuana is highly variable and it is often contaminated. Such contamination has little monitoring and is a public health concern [7]. Till date, four cases of myocarditis/perimyocarditis associated with marijuana use have been reported $[8,9,10,11]$. To the best of our knowledge, we hereby present the fifth case.

\section{Case Presentation}

A 27 year old male with a history of tobacco and marijuana abuse since the age of 17 presented with a chief complaint of substernal chest pain four hours after he smoked two joints of marijuana. He described the pain as sharp, intermittent, 6/10 in intensity, non-radiating, and was associated with a dry cough. He had an episode of fever a day prior to presentation. On presentation he was afebrile, heart rate was 87 beats per minute, blood pressure was 109/60 mm Hg. On physical examination, chest was clear to auscultation, S1 \& S2 heart sounds were heard, no murmur or friction rub were appreciated. Basic laboratory work up including complete blood count, comprehensive metabolic panel, coagulation profile, urine toxicology (DUA8) were obtained. A elevated white blood count of 17,800 white blood cells per microliter (mcL) with granulocyte count of 12,500 per $\mathrm{mcL}$ was noted. Electrolyte levels, liver enzymes and kidney functions were within normal limits. Urine toxicology was positive for THC. Chest X-ray was normal. Review of an electrocardiogram (EKG) obtained two years ago revealed normal sinus rhythm and no ST-T changes. EKG obtained during this visit showed normal sinus rhythm, diffuse ST-T segment elevation and PR segment depression (Image 1 and Image 2). Initial troponin value was elevated at $7.3 \mathrm{ng} / \mathrm{ml}$. The patient was diagnosed to have myopericarditis. However, as the troponin levels rose from $7.3 \mathrm{ng} / \mathrm{ml}$ to $25.7 \mathrm{ng} / \mathrm{ml}$, considering his history of marijuana use prior to presentation, a coronary angiogram was performed to rule out myocardial infarction. Coronary 
angiogram revealed normal coronary arteries. Subsequent troponin trends were as follows: 49.7, 29.4, 73.1,48.2, $29.4,33.4,17.2$, and $7.02 \mathrm{ng} / \mathrm{ml}$. Viral and bacterial etiology of myocarditis/pericarditis was ruled out. An echocardiogram (TTE) obtained showed normal left ventricular ejection fraction of 55\% and no regional wall motion abnormality or pericardial effusion were noted. Myopericarditis was managed with Ibuprofen and colchicine. Counseling was provided for marijuana use. The patient was discharged with a follow up appointment.

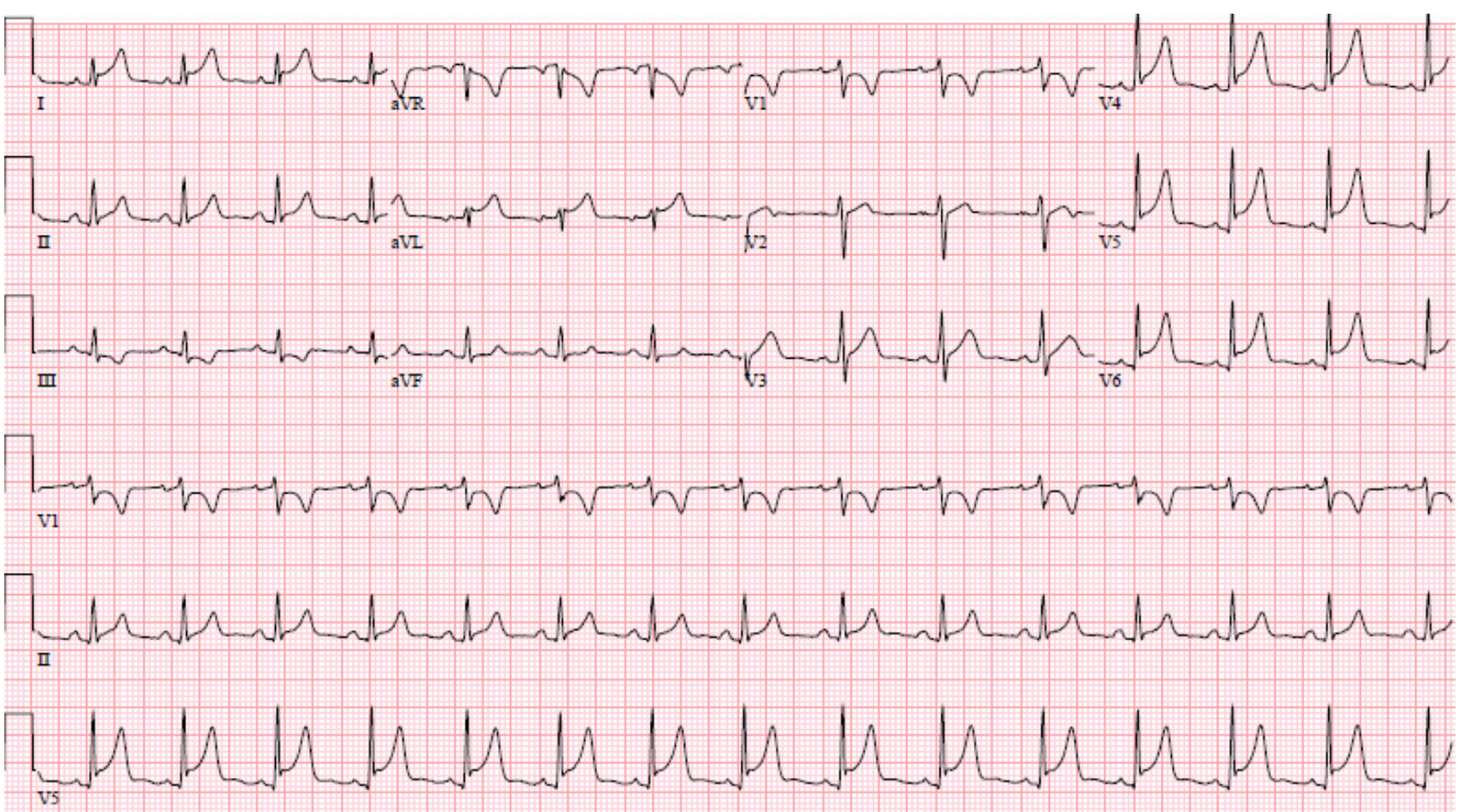

Image 1. EKG showing ST segment elevation in leads V2 to V6, I, aVL, T wave inversion in V2-V3, PR segment depression in V3 to V6, I and II and PR elevation and ST depression in aVR
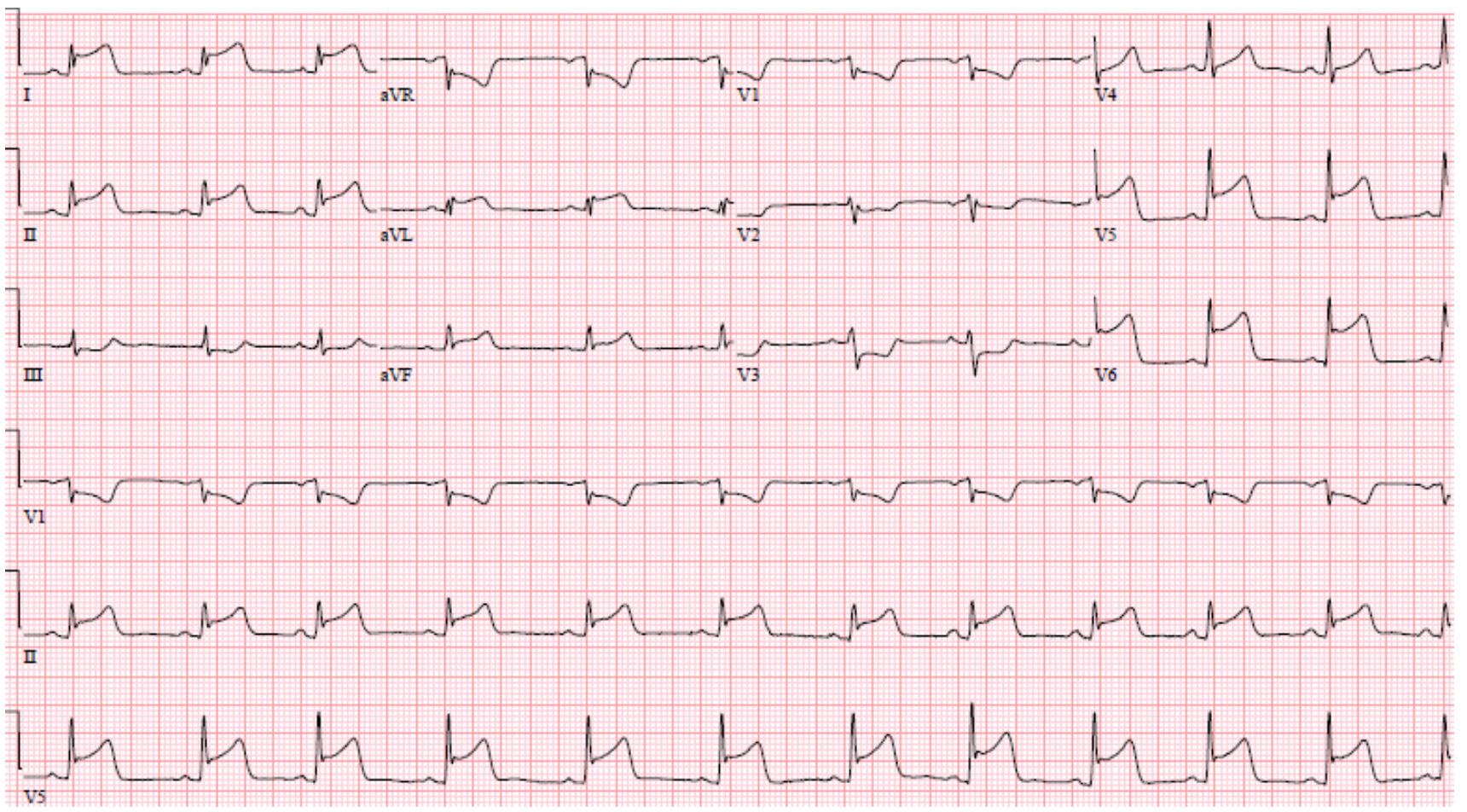

Image 2. EKG obtained after the initial EKG showing ST segment elevation in V4 to V6, I, II, aVL, ST segment depression in leads V1 to V3 and III, PR elevation and ST depression in aVR 


\section{Discussion}

Marijuana exerts various effects on the body via the cannabinoid receptors; $\mathrm{CB} 1$ and $\mathrm{CB} 2$. [6] CB1 and CB2 receptors are distributed over various tissues such as platelets, vascular smooth muscles and endothelium. CB1 agonism is atherogenic while CB1 antagonism and CB2 agonism is anti-atherogenic. [6]

It is difficult to regulate marijuana potency and contamination [7]. Fungi, bacteria, microbial toxins such as aflatoxinas, heavy metals and pesticides are among the contaminants reported in marijuana. Such contamination may carry additional health risks to the marijuana uses [7]. Aspergillus and penicillin specie fungi are known contaminants as well $[12,13,14]$. In addition, high levels of bacterial contamination have also been noted [15]. Heavy metals such as aluminium in soil may percolate to the marijuana plant and thus may become a contaminant thus, leading to an increase in the heavy metal load in the body upon smoking marijuana [16]. Pesticides used for pest control during marijuana cultivation can be a contaminant. High pesticide levels are noted in indoor grown marijuana when compared to naturally grown marijuana $[17,18]$. Many substances are added to "bulk up" marijuana [19] and glass has been noted as a contaminant to increase the crystalline appearance similar to resin glands [20].

Case reports of marijuana's association with pericarditis/myocarditis are rare but have been reported $[8,9,10,11]$ [Table 1]. The pathogenesis of pericarditis/ myocarditis related marijuana is unclear. One possible explanation is contaminants as possible cause. Further research to explore marijuana as a cause of myocarditis/ pericarditis/myopericarditis is needed.

Table 1. Previously published cases of myocarditis associated with marijuana use

\begin{tabular}{|c|c|c|c|c|c|c|c|}
\hline $\begin{array}{l}\text { Year of publication, } \\
\text { first author, } \\
\text { reported from }\end{array}$ & $\begin{array}{l}\text { Age (in } \\
\text { years) and } \\
\text { sex }\end{array}$ & $\begin{array}{l}\text { Presenting } \\
\text { complaint }\end{array}$ & EKG & Troponin & TTE & Diagnosis & Prognosis \\
\hline $\begin{array}{c}2008, \\
\text { Evangelos } \\
\text { Leontiadis, } \\
\text { Germany [8] }\end{array}$ & $\begin{array}{c}16 \text { years, } \\
\text { Male }\end{array}$ & $\begin{array}{l}\text { Acute heart } \\
\text { failure }\end{array}$ & $\begin{array}{c}\text { sinus } \\
\text { tachycardia, } \\
\text { right axis } \\
\text { deviation, slow } \\
\text { R-wave } \\
\text { progression in } \\
\text { leads V1-4 and } \\
\text { negative T } \\
\text { waves in leads } \\
\text { II, III, aVF, and } \\
\text { V4-6. }\end{array}$ & Normal & $\begin{array}{l}\text { Severely dilated left } \\
\text { ventricle with an } \\
\text { ejection fraction of } \\
15 \% \text { and global } \\
\text { hypokinesis, } \\
\text { moderate to severe } \\
\text { mitral regurgitation, } \\
\text { moderate pulmonary } \\
\text { hypertension, small } \\
\text { pericardial effusion, } \\
\text { and a mobile left } \\
\text { ventricular apical } \\
\text { thrombus. }\end{array}$ & Myocarditis & Recovered \\
\hline $\begin{array}{c}2014, \\
\text { Carlos E. Rodríguez } \\
\text {-Castro, United } \\
\text { States [9] }\end{array}$ & $\begin{array}{l}29 \text { years, } \\
\text { male }\end{array}$ & Chest pain & $\begin{array}{l}\text { ST-segment } \\
\text { elevation in the } \\
\text { inferior leads } \\
\text { with PR- } \\
\text { segment } \\
\text { depression }\end{array}$ & Elevated & $\begin{array}{l}\text { Ejection fraction of } \\
70 \% \text { with moderate } \\
\text { concentric } \\
\text { hypertrophy } \\
\text { consistent with } \\
\text { athlete's heart. No } \\
\text { wall motion } \\
\text { abnormalities seen. }\end{array}$ & Myopericarditis & $\begin{array}{l}\text { Recovered, had } \\
\text { a recurrence }\end{array}$ \\
\hline $\begin{array}{c}2016, \\
\text { J. Tournebize, } \\
\text { France }[10]\end{array}$ & $\begin{array}{l}15 \text { years, } \\
\text { male }\end{array}$ & Chest pain & Not specified & Elevated & Not obtained & Myocarditis & Recovered \\
\hline $\begin{array}{l}\text { 2017, Thomas M. } \\
\text { Nappe, United } \\
\text { States [11] }\end{array}$ & $\begin{array}{l}11 \text { months, } \\
\text { male }\end{array}$ & $\begin{array}{c}\text { central nervous } \\
\text { system (CNS) } \\
\text { depression and } \\
\text { then went into } \\
\text { cardiac arrest }\end{array}$ & $\begin{array}{c}\text { wide-complex } \\
\text { tachycardia. }\end{array}$ & $\begin{array}{c}\text { Not } \\
\text { reported }\end{array}$ & $\begin{array}{l}\text { Autopsy revealed a } \\
\text { non-dilated heart } \\
\text { with normal } \\
\text { coronary arteries }\end{array}$ & Myocarditis & Death \\
\hline
\end{tabular}

\section{Conclusion}

Potency and contaminants in marijuana are highly variable. Myocarditis/pericarditis/myopericarditis secondary to contaminants in marijuana as a cause should be suspected in young patients with marijuana use presenting with pericarditis. Additional research is needed to further establish the association between marijuana and myocarditis/pericarditis/myo-pericarditis. Along with the treatment with non-steroidal anti-inflammatory drugs and colchicine, abstinence from marijuana and avoiding passive smoking is of prime importance to avoid the occurrence and recurrence of marijuana related myocarditis/pericarditis/perimyocarditis.

\section{Acknowledgements}

This work is supported, in part, by the efforts of Dr. Moro O. Salifu M.D., M.P.H., M.B.A., M.A.C.P., Professor and Chairman of Medicine through NIH Grant number S21MD012474.

\section{References}

[1] Substance Abuse and Mental Health Services Administration. (2017). Key substance use and mental health indicators in the United States: Results from the 2016 National Survey on Drug Use and Health (HHS Publication No. SMA 17-5044, NSDUH Series H-52). Rockville, MD: Center for Behavioral Health 
Statistics and Quality, Substance Abuse and Mental Health Services Administration. Retrieved from https://www.samhsa.gov/data/

[2] Azofeifa A, Mattson ME, Schauer G, McAfee T, Grant A, Lyerla R. National Estimates of Marijuana Use and Related Indicators - National Survey on Drug Use and Health, United States, 2002-2014. MMWR Surveill Summ 2016; 65: 1-28.

[3] DEA website accessed on 4/29/2018 Retrieved from: https://www.dea.gov/druginfo/ds.shtml.

[4] PROCON.ORG. 29 legal medical marijuana states and DC: laws, fees, and possession limits. Retreived from:

$\mathrm{http}$ ://medicalmarijuana.procon.org/view.resource.php?resourceID $=00088$.

[5] Amar, Mohamed Ben. "Cannabinoids in medicine: A review of their therapeutic potential." Journal of ethnopharmacology105.1-2 (2006): 1-25.

[6] Kattoor A, Mehta JL. Marijuana and coronary heart disease. American College of Cardiology.

www.acc.org/latest-in-cardiology/articles/2016/09/22/08/58/ marijuana-and-coronary-heart-disease. September 22, 2016. Accessed July 5, 2017.

[7] McLaren, Jennifer, et al. "Cannabis potency and contamination: a review of the literature." Addiction 103.7 (2008): 1100-1109.

[8] Leontiadis, Evangelos, et al. "Thoratec left ventricular assist device removal after toxic myocarditis." The Annals of thoracic surgery 86.6 (2008): 1982-1985.

[9] Rodríguez-Castro, Carlos E., et al. "Recurrent myopericarditis as a complication of marijuana use." The American journal of case reports 15 (2014): 60.

[10] Tournebize, J., et al. "Myocarditis and cannabis: An unusual association." Toxicologie Analytique et Clinique 28.3 (2016): 236
[11] Nappe, Thomas M., and Christopher O. Hoyte. "Pediatric Death Due to Myocarditis after Exposure to Cannabis." Clinical Practice and Cases in Emergency Medicine 1.3 (2017).

[12] Kagen, Steven L., et al. "Marijuana smoking and fungal sensitization." Journal of allergy and clinical immunology 71.4 (1983): 389-393.

[13] Kurup, V. P., et al. "Allergenic fungi and actinomycetes in smoking materials and their health implications." Mycopathologia 82.1 (1983): 61-64.

[14] Verweij, Paul E., et al. "Fungal contamination of tobacco and marijuana." Jama 284.22 (2000): 2875-2875

[15] Hazekamp, Arno, Pieter Sijrier, and Rob Verpoorte. "An evaluation of the quality of medicinal grade cannabis in the Netherlands." Cannabinoids 1.1 (2006): 1-9.

[16] Exley, Christopher, et al. "Aluminum in tobacco and cannabis and smoking-related disease." The American journal of medicine 119.3 (2006): 276-e9.

[17] StollzNow. Market Research Report: Australians on Cannabis. Report Prepared for NDARC and Pfizer Australia. Sydney: StollzNow Research and Insights Advisory; 2006.

[18] Swift W., Gates P., Dillon P. Survey of Australians using cannabis for medical purposes. Harm Reduct J 2005; 2: 18.

[19] UK Cannabis Internet Activists. Cannabis Contamination. January 2007. Available at: http://www.ukia.org/library/ contam/default.php (accessed 28 June 2007).

[20] Department of Health. Alert-Contamination of Herbal or 'Skunk-Type' Cannabis with Glass Beads. 19 January 2007. Available at:

http://www.info.doh.gov.uk/doh/embroadcast.nsf/vwDiscussionAl 1/297D9740D0412C9D802572650050A4A0?OpenDocument. 